\title{
Adölesan Adneksiyel Kitlelerinde Cerrahi; 7 Yılda Tedavi Edilen 59 Hastanın Sonuçları
}

\author{
Surgery for Adolescent Adnexal Masses; 59 Patients Treated in a 7-Year Period
}

Yavuz Emre Șükür ${ }^{1}$, Mehmet Murat Seval' ${ }^{1}$, Batuhan Özmen ${ }^{1}$

Ankara Universitesi Tıp Fakültesi, Kadın Hastalıkları ve Doğum Anabilim Dalı, Ankara, Türkiye.
Geliș Tarihi : 12.07.2016• Kabul Tarihi: 11.10.2016

\section{İletișim}

Uz. Dr. Yavuz Emre Șükür

E-posta: yesukur@yahoo.com Tel: +90 3125956405

\begin{abstract}
Amaç: Adölesanlarda adneksiyel kitle görülme ihtimali üreme çağındaki kadınlara göre daha düșüktür ve bu kitlelerinin yönetimi fertilitenin korunması gerekliliği yönünden önemlidir. Bu çalıșmanın amacı, 7 yıllık bir dönemde kliniğimizde cerrahi uygulanan adneksiyel kitleli adölesan hastaları retrospektif olarak değerlendirmektir.

Gereç ve Yöntem: Retrospektif kohort çalıșması olarak dizayn edilen bu çalıșmaya Ankara Üniversitesi Tıp Fakültesi Kadın Hastalıkları ve Doğum Anabilim Dalı́nda 2006 ve 2012 yılları arasında adneksiyel kitle nedeniyle cerrahi yapılan tüm adölesan hastalar dahil edilmiștir $(n=59)$. Hastalara ait yaș, bașvuru semptomu, operasyon șekli, patolojik tanı ve tümör belirteçleri gibi bilgiler kaydedilmiștir.

Bulgular: Hastaların yaș ortalaması 17.8 \pm 2.5 yıl olarak hesaplanmıștır. Hastalara ait en sık bașvuru semptom ve bulguları sırasıyla karın ağrısı (\%57.6), karında șișlik (\%10.2) ve adet düzensizliğidir (\%10.2). Adölesan adneksiyel kitlelerinin muayene, görüntüleme yöntemleri ve tümör belirteçleri ile preoperatif değerlendirilmesinin malignite tanısı için duyarlılı̆ı \%83.3, özgüllüğü \%92.5, pozitif prediktif değeri \%55.5 ve negatif prediktif değeri \%98 olarak belirlenmiștir. Nihai patoloji sonucuna göre hastaların 40'ında (\%67.8) non-neoplastik kitle ve 19 'unda (\%32.2) neoplastik kitle tespit edilmiștir. Neoplastik adneksiyel kitlelerin ise $5^{\prime} \mathrm{i}$ matür teratom (\%8.5) ve 7'si kistadenom (\%11.8) tanısı almıștır. Bir hastada borderline seröz tümör (\%1.7) tespit edilirken, 6 hastada germ hücreli tümör (\%10.2) tespit edilmiștir.

Sonuç: Adölesanlarda fonksiyonel over kistleri ile sık karșılașilır. Kompleks görünümlü kistlerin ayırt edilmesinde USG bulguları ve tümör belirteçlerinin yeri önemlidir. Ádölesan adneksiyel kitlelerinin yönetiminde öncelikle daha az invaziv cerrahi yöntemler ve fertilite koruyucu müdahaleler tercih edilmelidir.

Anahtar Sözcükler: Adneksiyel Kitle, Adölesans, Ultrasonografi, Tümör Belirteci

Objective: The risk of adnexal mass is less in adolescents than in reproductive age women and those patients are important regarding fertility preservation. The aim of this study was to retrospectively evaluate adolescents operated for adnexal masses in our clinic in a 7 year period retrospectively.

Material and Methods: All patients operated for adnexal mass in Ankara University School of Medicine Department of Obstetrics and Gynecology between 2006 and 2012 were included in this retrospective cohort study. Data including age, presenting symptom, surgical method, pathologic diagnosis, and tumor markers are recorded.

Results: Mean age of the patients was $17.8 \pm 2.5$ years. The most common symptoms and signs of the patients were abdominal pain $(57.6 \%)$, abdominal swelling (10.2\%) ve menstral irregularities $(10.2 \%)$. The sensitivity, specificity, positive predictive value and negative predictive value of preoperative evalutation with physical examination, imaging and tumor markers for malignancy were $83.3 \%, 92.5 \%, 55.5 \%$, and $98 \%$ respectively. According to pathologic examination $40(67.8 \%)$ patients had non-neoplastic and $19(32.2 \%)$ patients had neolastic masses. Among neoplastic adnexal masses 5 (8.5\%) were mature teratoma and $7(11.8 \%)$ were cystadenoma. One (1.7\%) patient had borderline serous tumor and $6(10.2 \%)$ had germ cell tumors.

Conclusion: Functional ovarian cysts are common in adolescents. Ultrasonography findings and tumor markers are important in differential diagnosis of complex cysts. Less invasive surgical methods and fertility preserving procedures should be preferred in the management of adolescent adnexal masses.

Key Words: Adnexal Mass; Adolescence; Ultrasonography; Tumor Marker
\end{abstract}

Adölesans çocukluktan erișkinliğe geçiș dönemidir ve gelişimsel özellikler ve sağlık bakım ihtiyaçlarına göre erken adölesans (10-14 yaș), orta adölesans (15-17 yaş) ve geç adölesans (18-21 yaş) dönemlerine ayrılır (1). Kistik veya solid, herhangi bir ovaryen kitleye çocukluk ve adölesan çağlarında rastlanma ihtimali düșüktür (2). Çocukluk ve adölesan dönemlerinde karşılaşılan malignitelerin \%1-2'si ovaryen neoplazmlardır ve bu dönemlerde karşılaşılan abdominal malignitelerin $\% 8$ 'i overlerden kaynaklanmaktadır $(3,4)$. Bu lezyonlar arasinda fonksiyo- 
nel kist, over torsiyonu gibi non-neoplastik kitleler olabileceği gibi iyi huylu veya çok agresif seyreden malign neoplaziler de olabilir. Adölesanlarda siklikla benign neoplazmlara ve fonksiyonel kistlere rastlanırken cerrahi yap1lan over neoplazmlarının \%10-30'unda maliginite tespit edilmektedir (3).

Adölesanlarda adneksiyel kitlelerin ayırıcı tanısı cerrahi açıdan önemlidir. Başvuru semptomu karın ağrisı olan hastalarda peritonit ve akut apandisit ay1rıcı tanısı gereklidir. Karında şişlik ile başvuran hastalar malignite açısından değerlendirilmelidir. Ovaryen kitlesi olan çocuk veya adölesanlar prekoks puberte, maskülinizasyon veya diğer endokrin belirtilerle de başvurabilirler. Kitle etkisiyle üreteral baskı, hidroüreteronefroz, barsak tıkanıklığı veya solunum yetmezliği gelişebilir. $\mathrm{Bu}$ nedenlerle karın ağrısı, karında şişlik veya jinekolojik endokrin şikayetlerle başvuran adölesan hastaların ayırıcı tan1sinda ovaryen kitlelere mutlaka yer verilmelidir. Adölesan adneksiyel kitlelerinin değerlendirilmesinde jinekolojik ultrasonografi (USG), hormon seviyeleri ve tümör belirteçleri kullanılır. Eğer USG bulguları gerektirirse bilgisayarlı tomografi (BT) ve manyetik rezonans görüntüleme (MRG) de kullanılabilir. Doğru değerlendirme sonrasında en uygun tedavinin seçilmesi kolaylaşır. Sıklıkla gözlem ve bekle-gör tedavisi yeterlidir. Benign over tümörleri için cerrahi müdahale over rezervini azaltabilir, adezyonlara neden olabilir ve laparotomik cerrahi ilerleyen dönemlerde alt batın semptomlarına neden olabilir. Laparoskopik cerrahide ise daha memnun edici sonuçlar elde edilir (5). Dolayısıyla, çocukluk ve adölesans dönemlerinde mümkün olduğunca konservatif yaklaşım ve gerekirse laparoskopik over koruyucu cerrahilerin uygulanması daha uygun görünmektedir.

Bu çalışmanın amac1, 7 yıllık bir dönemde kliniğimizde cerrahi uygulanan adneksiyel kitleli adölesan hastaları retrospektif olarak değerlendirmek ve deneyimlerimizi aktarmaktır.

\section{Gereç ve Yöntem}

Retrospektif kohort çalışması olarak dizayn edilen bu çalışmaya Ankara Üniversitesi Tıp Fakültesi Kadın Hastalıkları ve Doğum Anabilim Dalı'nda 2006 ve 2012 yilları arasinda adneksiyel kitle nedeniyle cerrahi yapilan tüm adölesan hastalar dahil edilmiştir $(\mathrm{n}=59)$. Çalışmaya dahil edilme kriterleri arasinda hastaneye pelvik veya adneksiyel kitle tanısıyla yatmış olmak, yaşın 10 ile 21 arasında olması yer almaktadır. Çalışmaya dahil edilmeme kriterleri ise cerrahi tedavi uygulanmamış olması ve patolojik tanıya ulaşılamamasidir.

Çalışmaya dahil edilen hastaların tümüne ait tıbbi kayıtlar incelenmiş ve yaş, başvuru semptomu, operasyon şekli ve patolojik tanı gibi bilgiler kaydedilmiştir. Ayrica hastalara ait preoperatif AFP, CA125, CA19-9, CEA, ve $\beta$ hCG gibi tümör belirteçlerinin değerleri kaydedilmiştir. Hastaların ilk muayeneleri, ultrasonografi incelemeleri ve tümör belirteçlerine göre elde edilen preoperatif taniları, operasyon ve patolojik inceleme ile elde edilen nihai patolojik tanılarıyla karşılaştırılmıştır.

\section{Bulgular}

Çalışma kapsamında taranan 7 yıl boyunca kliniğimizde toplam 59 adölesan hasta adneksiyel kitle nedeniyle cerrahi tedavi görmüştür. Hastaların yaşları 10 ile 21 arasında değişmektedir. Çalışmaya dahil edilen hastaların yaş ortalaması 17.8 \pm 2.5 yıl olarak hesaplanmıştır. Hastalara ait en sık başvuru semptom ve bulguları sırasıly karın ağrıs1 (\%57.6), karında şişlik (\%10.2) ve adet düzensizliği (\%10.2) olarak belirlenmiştir (Tablo 1). Hastaların 7'sinde (\%11.9) ise adneksiyel kitle başka bir nedenle yapılan değerlendirmeler esnasinda rastlantisal olarak tespit edilmiştir. Hastaların 7'sinde CA125, 3'ünde CA19-9, ve 6'sinda AFP yüksek tespit edilmiştir. CA125'i yüksek olan hastaların 2'sinde (\%28.6) malignite (immatür kistik teratom) tespit edilirken, AFP'si yüksek olan hastaların tamamında malignite (germ hücreli tümörler) tespit edilmiştir.

Operasyon öncesinde 50 hastada muayene, görüntüleme ve tümör belirteçleri sonuçlarına göre ön tanı benign olarak düşünülmüştür. Bu hastalardan sadece birinde patolojik inceleme sonrasında malignite, immatür kistik teratom, tespit edilmiştir. On iki yaşındaki bu hastaya acil şartlarda over torsiyonu ön tanısıyla müdahale edilmiş ancak immatür kistik teratom tespit edilmesi üzerine debulking cerrahisi uygulanmıştır. Operasyon öncesinde 9 hastada ise muayene, görüntüleme ve tümör belirteçleri sonuçlarına göre ön tanı malign olarak düşünülmüştür. $\mathrm{Pa}$ tolojik inceleme sonrasinda ise bu hastaların 5'inde malignite tespit edilmiştir. Bir hastada borderline seröz tümör, iki hastada over torsiyonu ve bir hastada ise matür kistik teratom tespit edilmiștir. Buna göre adölesan adneksiyel kitlelerinin muayene, görüntüleme yöntemleri ve tümör belirteçleri ile preoperatif değerlendirilmesinin malignite tanısı için duyarlılığı \%83.3, özgüllüğü $\% 92.5$, pozitif prediktif değeri $\% 55.5$ ve negatif prediktif değeri \%98 olarak belirlenmiştir (Tablo 2).

Otuz yedi hastada laparoskopik cerrahi uygulanırken (\%62.7), 22 hastada (\%37.3) açık cerrahi uygulanmıştır. Hastaların 31'inde (\%52.5) acil cerrahi müdahale yapılmıştır. Hastaların 6'sinda (\%10.2) ovaryen kitlenin torsiyone olduğu izlenmiștir. Tablo 3'te hastalara ait nihai patoloji sonuçları özetlenmiştir. Nihai patoloji sonucuna göre hastaların 40'1nda (\%67.8) nonneoplastik kitle ve 19'unda (\%32.2) neoplastik kitle tespit edilmiştir. Nonneoplastik adneksiyel kitlelerin 30’u fonksiyonel over kisti (\%50.8), 5’i endometrioma (\%8.5), 4'ü paraovaryen kist $(\% 6.8)$ ve 1 'i hidrosalpinks olarak (\%1.7) belirlenmiştir. Neoplastik adneksiyel kitlelerin ise 5 'i matür teratom (\%8.5) ve 7'si kistadenom (\%11.8) tanısı almıştır. Bir hastada borderline seröz tümör (\%1.7) tespit edilirken, 6 hastada germ hücrel tümör $(\% 10.2)$ tespit edilmiştir. 
Tablo 1. Hastaların başvuru sırasındaki semptomları.

\begin{tabular}{lll} 
Bașvuru semptomları & $\mathbf{N}$ & \% \\
\hline Karın ağrısı & 34 & 57.6 \\
Karında șișlik & 6 & 10.2 \\
Ele gelen kitle & 4 & 6.8 \\
Menstruasyon düzeninde bozulma & 6 & 10.2 \\
Rastlantısal & 7 & 11.9 \\
Kusma & 2 & 3.4 \\
\hline
\end{tabular}

Tablo 2. Fizik muayene, ultrasonografi ve tümör belirteçlerinin birlikte adölesan malignitelerindeki tanısal değeri

\begin{tabular}{lc} 
FM+USG+TB & $\%$ \\
\hline Duyarlılık & 83.3 \\
Özgüllük & 92.5 \\
Pozitif prediktif değer & 55.5 \\
Negatif prediktif değer & 98
\end{tabular}

Not: FM: fizik muayene; USG: ultrasonografi; TB: tümör belirteci

Tablo 3. Hastalara ait patolojik bulgular.

\begin{tabular}{lll} 
Patoloji & N & \% \\
\hline Non-neoplastik & $\mathbf{4 0}$ & $\mathbf{6 7 . 8}$ \\
Fonksiyonel kist & 30 & 50.8 \\
Folikül kisti & 17 & 28.8 \\
Korpus luteum & 13 & 22 \\
Endometrioma & 5 & 8.5 \\
Paraovaryen kist & 4 & 6.8 \\
Hidrosalpinks & 1 & 1.7 \\
Neoplastik & $\mathbf{1 9}$ & $\mathbf{3 2 . 2}$ \\
Benign & 12 & 20.3 \\
Matür teratom & 5 & 8.5 \\
Kistadenom & 7 & 11.8 \\
Malign/Borderline & 7 & 11.8 \\
Germ hücreli tümör & 6 & 10.2 \\
Disgerminom & 2 & 3.4 \\
İmmatür teratom & 2 & 3.4 \\
Mikst germ hücreli tümör & 2 & 3.4 \\
Epitelyal & 1 & 1.7 \\
Seröz tümör (borderline) & 1 & 1.7 \\
\hline
\end{tabular}

\section{Tartıșma}

Çalışmamızın sonuçlarına göre adölesan adneksyel kitlelerinde en s1k başvuru semptomları sırasıyla karın ağrısı, karında şişlik ve menstrüel düzensizliktir. Malign over tümörlerinde en s1k yükselen tümör belirteci AFP'dir. Malignite tanısı için muayene, görüntüleme yöntemleri ve tümör belirteçleri ile preoperatif değerlendirmenin pozitif prediktif değeri $\% 55.5$ ve negatif prediktif değeri \%98'dir. Adölesan adneksiyel kitlelerinde sıklıkla laparoskopik cerrahi uygulanmaktadır. Adölesan adneksiyel kitlelerinin sıklıkla non-neoplastik olduğu, bunların da sıklıkla fonksiyonel over kistleri olduğu belirlenmiştir. Neoplastik kitlelerin ise siklıkla benign olduğu ve bu yaş grubunda en s1k malignitenin germ hücreli over tümörleri olduğu belirlenmiştir.

Adölesan ve çocukluk dönemi over patolojilerinde başvuru semptomları çeşitlidir ve özgün değildir. Ayrıca, bu yaş aralığında over patolojileriyle nadir karşılaşıldığından akut karın ağrısı gibi
Özgün olmayan semptomlar akut apandisit gibi daha sık görülen patolojileri düşündürebilir. Bu nedenle preoperatif dönemde doğru tanı koymak kolay olmayabilir. Daha önce adölesan adneksiyel kitlelerini değerlendiren çalışmalarda en sık başvuru semptomu olarak karın ağrısı (\%56-78) bildirilmiştir. Diğer sık bildirilen semptomlar ise karında şişlik-ele gelen kitle (\%6.839), menstrüel bozukluklar (\%5-18.2) ve kusma (\%18) olarak bildirilmiştir. $\mathrm{Bu}$ dönemdeki adneksiyel kitlelerin 
\%6-13.7'si ise başka bir sebeple değerlendirilen hastalarda rastlantısal olarak tespit edilmiştir. Bizim çalışmamızın sonuçları semptomların dağılımı yönünden literatür ile benzerlik göstermektedir.

Çocukluk ve adölesan dönemlerindeki tüm tümörlerin yaklaşık \%1’i over kaynaklıdır ve tüm ovaryen malignitelerinin $\% 5$ 'ine bu yaş grubunda rastlanır (7). Daha önce yapılan çalışmaların sonuçlarına göre de adölesanlarda ovaryen kitlelerin çoğu non-neoplastiktir (7-9). Bir çalışmaya göre 21 yaş altında non-enflamatuar ovaryen kitle nedeniyle ameliyat edilen hastaların $\% 57.9$ 'unda non-neoplastik basit kist vardir (8). Deligeoroglou ve ark. (7),'nın çalışmasına göre de adölesan adneksiyel kitlelerinin \%49'undan non-neoplastik over kistleri sorumludur. Cass ve ark (6),'nın çalışmasında non-neoplastik kitlelerin oranı \%46.2 olarak bildirilmiştir. Başka bir çalışmada ise non-neoplastik kitlelerin oranı daha düşük (\%33) olarak bildirilmiştir (6). Bizim çalışmamızın sonuçlarına göre ise non-neoplastik kitlelerin oranı literatürdeki oranlardan daha yüksektir (\%67.8). Bunun nedeni over dışındaki patolojilerin de (paraovaryen kist ve hidrosalpinks gibi) bu gruba dahil edilmiş olması ve acil şartlarda cerrahi uygulanan hastaların sonuçlarının da değerlendirilmesi olabilir.

Fonksiyonel over kistleri folikül kisti, korpus luteum kisti ve teka lutein kistlerinden oluşur. Siklıkla spontan rezolüsyon görülse de yaklaşı \%25'inde persistans nedeniyle cerrahi tedavi gerekir (7). Folikül kistleri için sıklıkla USG tanı için yeterlidir. Folikül kistlerinin takibi sırasında hipotalamikovaryen aksı baskılamak ve yeni bir kist oluşumunu engellemek amaciyla hastaya oral kontraseptif başlanması sik tercih edilen bir yöntemdir. Ancak modern oral kontraseptifler fonksiyonel over kisti oluşumunu engellememektedir (10). Korpus luteum kistlerinin ise USG'de daha karmaş1k bir görünümü vardır ve kanama nedeniyle ayırıcı tanıları zorlaşabilir. Bizim kohortumuzda bulunmayan teka lutein kistleri ise çok daha nadir görülür. S1klıkla bilateral, gebelikte ve özellikle molar gebeliklerde görülürler. Boyutları çok büyük olabilir ve sıklıkla spontan rezolüsyon görülür (11). Endometriomalar her ne kadar adölesan döneminde daha nadir görülseler de bizim çalışmamızdaki hastaların \%8.5'inde tespit edilmiştir. Endometriomalar sıklıkla daha küçüktürler, iyi sınırlı görünürler ve internal ekojenite içerirler. Nadiren solid bir görünüm de sergileyebilirler. Paraovaryen kistler over patolojileriyle karışabilir. Broad ligament kaynaklı bu kistler mezotelyal, paramezonefrik veya nadiren mezonefrik kaynaklı olabilir (12). Paraovaryen kistler değișen boyutlarda görülebilir ve fonksiyonel kistlerle karışabilir. Tanıda ayırıcı olan takiple kistin boyut ve görünümünde değişiklik olmamasıdir. Nadiren malignite ( $\% 2)$ bildirilen paraovaryen kistlerin tedavisi cerrahi$\operatorname{dir}(13)$.

Yirmi beş yaşından daha genç kadınlarda over kanseri en s1k jinekolojik malignitedir ve bu yaşlarda en sık görülen tipi germ hücreli tümörlerdir (14). Germ hücreli tümörler tüm over neoplazmlarının \%20-25'ini oluşturmaktadır ve bunların da sadece \%3'ü maligndir. Germ hücreli tümörlerin USG görüntüleri değişken olmakla birlikte, dermoid kistler içerisinde bulunan diş, saç ve yağ dokuları nedeniyle ayırt edilebilirler. Adölesanlarda görülen ikinci sık neoplastik tümörler ise epitelyal neoplazmlardır ve insidansı artan yaşla birlikte artar (15). En sik görülen iki tipi seröz ve müsinöz tümörlerdir. Bizim çalışmamızın sonuçları da literatür ile uyumludur. Hastaların yaklaşık $\% 20$ 'sinde benign neoplastik tümörler izlenirken, yaklaşık \%10'unda malign neoplastik tümörler tespit edilmiştir. $\mathrm{Bu}$ çalışmanın kohortunda 5 hastada (\%8.5) dermoid kist izlenmiştir ve bunların 2'sinde patolojinin bilateral olduğu görülmüştür. Maliginitelerin ise tamamı germ hücreli tümörlerdir.

Çocukluk ve adölesan dönemlerinde over torsiyonuna daha sik rastlanmaktadır (6). Bu hastalar genellikle akut karın ağrısı ve bulantı-kusma ile başvururlar. Over torsiyonu sağda daha sık görüldüğünden akut apandisit ile karıştırılabilir (2). Over torsiyonlarinin solda daha az görülmesinin muhtemel sebebi sigmoid kolonun torsiyona karş1 koruyucu olmas1 olabilir. over torsiyonlarının yaklaşı $\% 75$ 'inde overde solid veya kistik bir kitle bulunmaktadir (2). Her ne kadar USG faydalı olsa da bazen kesin tanı için cerrahi müdahale gerekebilir. Bizim çalışmamızda hastaların \%10'unda over torsiyonuna rastlanmıştır ve tümünde torsiyonun nedeni ovaryen kist veya tümörlerdir. Torsiyonların \%67'si sağ (4/6) ve \%33’ü sol (2/6) overde izlenmiştir.

Cerrahi öncesi tanı koyulmasında ve malign kitlelerin cerrahi sonrasında takibinde tümör belirteçleri önemlidir (16). Bir onkofetal antijen olan AFP glikoprotein yapıdadır ve özellikle endodermal sinüs tümörü, mikst germ hücreli tümör, ve immatür teratomlar tarafindan üretilir. Laktat dehidrogenaz (LDH) ise disgerminomlarda yükselir. Karsinoembriyonik antijen (CEA) epitelyal veya germ hücreli tümörlerce salglanır. hCG ise koryokarsinom, embryonel over kanseri ve mol hidatiformda yükselir. CA125 ise epitelyal over kanseri için duyarlılığ1 yüksek olan ancak özgüllüğü yeterli olmayan bir tümör belirtecidir (16). Bizim çalışmamızda da özellikle malign kitlelerde tümör belirteçlerinin yükseldiği ve germ hücreli tümörlerin tümünde AFP'nin arttığ1 tespit edilmiştir. Tümör belirteçleri ile muayene bulguları ve görüntüleme yöntemleri birlikte değerlendirildiğinde duyarlıllğın \%83.3 ve özgüllüğün \%92.5 olduğu belirlenmiştir.

Sonuç olarak, adölesan adneksiyel kitleleri karın ağrısı, karında şişlik, menstrüel siklusta düzensizlik, bulantı-kusma gibi değişik semptomlarla başvurabilir. Adölesanlarda basit veya kompleks görünümlü fonksiyonel over kistleri ile sık karşılaşılmaktadır. Folikül kistleri genellikle tedavisiz iyileşse de kistin boyutu ve semptoma bağlı olarak cerrahi gerekebilir. Kompleks görünümlü kistlerin ayırt edilmesinde USG bulguları ve tümör belirteçlerinin yeri önemlidir. Adölesanlarda öncelikle laparoskopi gibi daha az invaziv cerrahi yöntemler tercih edilmedir ve ne sebeple cerrahi yapılmış olursa olsun fertilite koruyucu müdahaleler tercih edilmelidir. 


\section{KAYNAKLAR}

1. Behrman RE. Adolescent Gynecology. In Behrman RE, Kliegman RM, editör. Nelson Essential for Pediatrics, 4. Baskı Philadelphia, PA: WB Saunders, 2002, p. 259 260.

2. Laufer MR, Benign and malignant ovarian masses In: Emans SJ, Laufer MR, Goldstein DP, editör. Pediatric and Adolescent gynecology 3. Bask1 Philadelphia; 1998. $\mathrm{P}=553$ 585 .

3. Brown MF, Hebra A, Mc Geehin K, et al. Ovarian masses in children: a review of 91 cases of malignant and benign masses. J Pediatr Surg 1993; 28: 930-933.

4. Piippo S, Mustaniemi L, Lenko H, et al. Surgery for ovarian masses during childhood and adolescence: a report of $79 \mathrm{ca}-$ ses. J Pediatr Adolesc Gynecol 1999; 12: 223-227.

5. Yuen PM, Yu KM, Yip SK, et al. A randomized prospective study of laparoscopy and laparotomy in the management of benign ovarian masses. Am J Obstet Gynecol 1997; 177: 109-114.
6. Cass DL, Hawkins E, Brandt ML, et al Surgery for ovarian masses in infants, children, and adolescents: 102 consecutive patients treated in a 15 -year period. J Pediatr Surg 2001; 36: 693-699.

7. Deligeoroglou E, Eleftheriades M, Shiadoes V, et al. Ovarian masses during adolescence: clinical, ultrasonographic and pathologic findings, serum tumor markers and endocrinological profile. Gynecol Endocrinol 2004; 19: 1-8.

8. Templeman C, Fallat ME, Blinchevsky A et al. Noninflammatory ovarian masses in girls and young women. Obstet Gynecol 2000; 96: 229-233.

9. Van Winter JT, Simmons PS, Podratz KC Surgically treated adnexal masses in in fancy, childhood, and adolescence. Am J Obstet Gynecol 1994; 170: 1780-1786.

10. Holt VL, Cushing-Haugen KL, Daling JR Oral contraceptives, tubal sterilization, and functional ovarian cyst risk. Obstet Gynecol 2003; 102:252-258.
11. Joshi R, Dunaif A. Ovarian disorders of pregnancy. Endocrinol Metab Clin North Am 1995; 24: 153-169.

12. Athey PA, Cooper NB. Sonographic features of paraovarian cysts. AJR Am J Roentgenol 1985; 144: 83-86.

13. Stein AL, Koonings PP, Schlaerth JB, et al Relative frequency of malignant paraovarian tumors: should paraovarian tumors be aspirated? Obstet Gynecol 1990; 75: 10291031.

14. You W, Dainty LA, Rose GS, et al. Gynecologic malignancies in women aged less than 25 years. Obstet Gynecol 2005; 105:1405-1409.

15. Pfeifer SM, Gosman GG. Evaluation of adnexal masses in adolescents. Pediatr Clin North Am 1999; 46: 573-592.

16. Papic JC, Finnell SM, Slaven JE, et al. Predictors of ovarian malignancy in children: overcoming clinical barriers of ovarian preservation. J Pediatr Surg 2014; 49: 144 147. 
